Dariusz Strzębicki

Szkoła Gtówna Gospodarstwa Wiejskiego

\title{
Uwarunkowania rozwoju systemów ERP w przedsiębiorstwach
}

\section{CONDITIONS FOR DEVELOPING ERP SYSTEMS IN ENTERPRISES}

\begin{abstract}
Celem artykułu była identyfikacja czynników, które maja wptyw na proces wdrażania systemów ERP $w$ przedsiębiorstwach. Celem była również określenie tendencji zmian $w$ oferowanych przez dostawców systemach ERP dla przedsiębiorstw $w$ Polsce. Artykut oparto na przegladzie literatury z zakresu wdrażania systemów klasy ERP oraz na dostęnych $w$ sieci Internet danych wtórnych. Analiza wykazała, że współczesne systemy ERP w coraz większym stopniu przyczyniaja się do coraz większej automatyzacji procesów oraz sq w coraz większym stopniu nakierowane na rozwój integracji zewnętrznej przedsiębiorstw. $W$ artykule pokazano również, że na każdym z etapów procesu innowacji występuje wiele czynników mogacych mieć wplyw na niepowodzenie projektu wdrażania ERP. Czynniki wptywajace na rozwój systemu ERP moga tkwić $w$ przedsiębiorstwie jak i pochodzić z jego otoczenia.
\end{abstract}

Słowa kluczowe: ERP, planowanie zasobów przedsiębiorstwa, systemy informacyjne, technologie informacyjne.

Wstęp

Zmienne otoczenie oraz narastająca konkurencja w branży sprawiają, że przedsiębiorstwa są zmuszone do przetwarzania coraz większej ilości informacji na każdym poziomie oraz w każdym dziale organizacji. Umiejętne korzystanie z informacji pozytywnie oddziałuje na płynność i ciagłość procesów oraz skuteczne podejmowanie decyzji w przedsiębiorstwie. Aby radzić sobie z dużymi ilościami ważnych informacji przedsiębiorstwa coraz częściej sięgają do rozwiązań informatycznych. Do najbardziej złożonych systemów informacyjnych, z których korzystają przedsiębiorstwa można zaliczyć systemy ERP (Enterprise Resource Planning). Ze względu na swą złożoność systemy te nie są łatwe we wdrażaniu i jednocześnie są bardzo kosztowne. Skuteczna implementacja systemu ERP stanowi dla przedsiębiorstw duże wyzwanie i może zależeć od wielu czynników. Pomimo tego przedsiębiorstwa coraz częściej decydują się na wdrażanie tych systemów spodziewając się wielu korzyści z ich stosowania.

Celem artykułu jest próba identyfikacji czynników, które mają wpływ na proces wdrażania systemów ERP w przedsiębiorstwach. Drugim celem artykułu jest określenie tendencji zmian w oferowanych przez dostawców systemach ERP dla przedsiębiorstw w Polsce. Artykuł oparto na przeglądzie literatury z zakresu wdrażania systemów klasy ERP oraz na dostępnych w sieci Internet danych wtórnych. 


\section{Istota systemów ERP}

ERP (Eneterprise Resource Planning) definiuje się jako system informacyjny integrujący procesy biznesowe $\mathrm{w}$ całej organizacji ${ }^{1}$. Jest systemem zaprojektowanym $\mathrm{w}$ celu optymalizacji i integracji procesów i transakcji w przedsiębiorstwie. Systemy ERP umożliwiają swobodny przepływ informacji w obrębie całej organizacji. Integrują one różne podsystemy $\mathrm{w}$ jeden duży system informacyjny oparty na jednej bazie danych. Połączone podsystemy informacyjne w przedsiębiorstwie dają efekt tak zwanej integracji przejawiającej się w tym, że procesy łańcucha wartości stają się silnie ze sobą powiązane i oddziaływają na siebie wzajemnie ${ }^{2}$. Wyróżnia się dwa rodzaje integracji: wewnętrzną $\mathrm{W}$ obrębie przedsiębiorstwa oraz zewnętrzną $\mathrm{z}$ systemami otoczenia przedsiębiorstwa ${ }^{3}$.

System ERP stanowi rozwiązanie informatyczne pochodzące od pojedynczego twórcy oprogramowania. Integruje on głównie takie funkcje przedsiębiorstwa jak: produkcja, dystrybucja, sprzedaż, finansowanie, zarządzanie zasobami ludzkimi. Różnorodność w przedsiębiorstwie aplikacji, które pochodzą od wielu dostawców ogranicza przepływ informacji w przedsiębiorstwie. Celem wprowadzenie pojedynczego zintegrowanego systemu informacyjnego jest zapobieżenie zróżnicowaniu używanych w przedsiębiorstwie aplikacji pochodzących od różnych dostawców, które ograniczają przepływ informacji w przedsiębiorstwie ${ }^{4}$.

Systemy ERP mają swe korzenie w pierwszej generacji zintegrowanych systemów zarządzania jakimi były systemy MRP (planowania potrzeb materiałowych), których głównym zadaniem była redukcja zapasów, wyznaczanie kosztów produkcji, kontrola etapów produkcji oraz określenie terminów dostaw surowców i komponentów do produkcji ${ }^{5}$. Początkowo systemy MRP opierały się na harmonogramach produkcji oraz danych o procesie produkcji. Do systemów ERP dodawano nowe moduły związane z planowaniem produkcji, zarządzaniem zapasami i popytem i w tej postaci nazwano je MRP II (planowanie zasobów produkcyjnych). Z MRP II wyewoluowała klasa ERP poprzez dodanie modułów związanych $\mathrm{z}$ planowanie zasobów finansowych, zarządzaniem zasobami ludzkimi, księgowością, finansami, zarządzanie projektami. Wzbogacenie systemu ERP o funkcje internetowe, technologie mobilne oraz standard XML nazywane jest powszechnie klasą ERP II ${ }^{6}$.

Współczesne systemy ERP jeśli są odpowiednio wprowadzone do przedsiębiorstw mogą im przynieść wiele korzyść. Do przykładowych korzyści z używania systemów ERP można zaliczyć: większą dokładność, szybkość oraz dostępność informacji, automatyzację procesów, poprawę wymiany informacji i interakcji między działami przedsiębiorstwa, poprawę współpracy $\mathrm{z}$ dostawcami, usprawnienie procesów produkcyjnych, lepsze planowanie produkcji, lepsze

\footnotetext{
${ }^{1}$ K. Kumar, J. Van Hillsgersberg: ERP experiences and evolution, Communications of the ACM, 43(4) 2000, s. 23.

${ }^{2}$ A. Ray, R. Patnayakani, N. Seth: Firm performance impacts, of digitaly-enabled supply chain integration capabilities, MIS Quarterly 30(2) 2006, s. 227.

${ }^{3}$ A. Lenart: Systemy ERP, (W:) Informatyka ekonomiczna (red. S. Wrycza), Wyd. PWE, Warszawa 2010, s. 346.

${ }^{4}$ P. Bocij, D. Chaffey, A. Greasley, S. Hickie: Business information systems, Pearson Education, Essex 2006, s. 55.

${ }^{5}$ A. Partyka: Analiza porównawcza systemów klasy ERP, Współczesna Ekonomia Nr 2/2008(6), s. 144.

${ }^{6}$ Ibidem s. 144.
} 
wykorzystanie zasobów, redukcję czasu cyklu produkcji, zmniejszenie poziomu zapasów, poprawę w obsłudze zamówień, większą dokładność i przejrzystość informacji finansowych, poprawę zdolności podejmowania decyzji, poprawę obsługi nabywców, poprawę satysfakcji nabywców, poprawę zarządzania zasobami ludzkimi ${ }^{7}$.

\section{Funkcje systemu ERP}

System ERP jest oprogramowaniem, które jest zazwyczaj nabywane przez przedsiębiorstwo jako gotowe rozwiązanie. Dopiero później jest ono dostosowywane do konkretnych potrzeb przedsiębiorstwa. Jest to o wiele tańsze rozwiązanie w porównaniu tworzenia oprogramowania ERP $\mathrm{w}$ przedsiębiorstwie od podstaw. Jest również obarczone mniejszą liczbą błędów działania oraz bazuje na sprawdzonych metodach i najlepszych praktykach firm z branży. Cechą charakterystyczną gotowych systemów ERP jest ich modułowość. Przedsiębiorstwo może zdecydować się na zakup tylko jednego z oferowanych modułów, jednakże większe korzyści zakresu oraz pełną integrację technologiczną przedsiębiorstwa osiagają wdrażając wiele modułów jednocześnie. Jak pokazuje przeprowadzona przez autora analiza oferty jednego $\mathrm{z}$ największych polskich producentów oprogramowania ERP, przedsiębiorstwo chcące wdrożyć system tej klasy oprócz klasycznego pakietu ERP może również zakupić moduły pozwalające na współpracę systemu z urządzeniami mobilnymi, sprzedażą internetową oraz realizację innych dodatkowych funkcji. Funkcje modułów ERP oferowane przez jednego z polskich twórców autor zakwalifikował do 3 kategorii: funkcje podstawowe, funkcje uniwersalne, funkcje sprzedażowe. W tabeli 1 zaprezentowano funkcje podstawowe. Do funkcji podstawowych zaliczono klasyczne moduły systemów ERP, które są związane z określonym działem przedsiębiorstwa.

Tabela 1. Funkcje podstawowe systemu ERP

\begin{tabular}{|c|c|}
\hline Nazwa funkcji & Opis funkcji \\
\hline Produkcja & $\begin{array}{l}\text { Wsparcie działań produkcyjnych m.in. optymalizacja procesów wytwórczych, } \\
\text { ustalanie kosztów produkcji, wsparcie działań okołoprodukcych. }\end{array}$ \\
\hline Serwis i & Wsparcie ewidencji i realizacji zleceń serwisowych. \\
\hline Hanc & $\begin{array}{l}\text { Wsparcie procesów handlowych i dystrybucyjnych od strony sprzedażowej oraz } \\
\text { zakupowej. Realizacja transakcji krajowych i zagranicznych. }\end{array}$ \\
\hline $\begin{array}{l}\text { Gospodarka } \\
\text { magazynowa }\end{array}$ & $\begin{array}{l}\text { Wsparcie procesów logistycznych m.in. realizacja dyspozycji magazynowych, } \\
\text { kontrola nad poziomem zapasów, wsparcie transportu. }\end{array}$ \\
\hline CRM & $\begin{array}{l}\text { Umożliwia tworzenie rozbudowanej bazy wiedzy o nabywcach, zbieranie } \\
\text { informacji rynkowych oraz prowadzenie kampanii promocyjnych. }\end{array}$ \\
\hline Finanse & $\begin{array}{l}\text { Elektroniczna obsługa finansów przedsiębiorstwa z elastycznym generowaniem } \\
\text { sprawozdań finansowych oraz obsługą księgowości. }\end{array}$ \\
\hline Środki trwałe & $\begin{array}{l}\text { Wsparcie obszaru zarządzania środkami trwałymi od strony wprowadzania i } \\
\text { ewidencji wraz z automatycznym naliczaniem odpisów amortyzacyjnych. }\end{array}$ \\
\hline $\mathrm{Hu}$ & Usprawnienie procesów kadrowo-płacowych. \\
\hline E-pracownik & $\begin{array}{l}\text { Zarządzanie pracownikami m.in. wyznaczanie celów, ocena i monitorowanie } \\
\text { pracowników. }\end{array}$ \\
\hline
\end{tabular}

Źródło: Opracowanie własne na podstawie broszury produktowej firmy Comarch „Comarch ERP XL Zintegrowany system do zarządzania przedsiębiorstwem", http://www.comarch.pl/files-pl/file_64/ComarchERP-XL.pdf.

${ }^{7}$ S. Sadrzadehrafiei, A. G. Chofreh, N. Hosseini, R. Sulaiman: The benefits of enterprise resource planning (ERP) system implementation in dry food packaging industry, Procedia Technology 11(2013), s. 225. 
Do funkcji uniwersalnych zaliczono funkcje, które wspierają procesy wielu działów przedsiębiorstwa. Zaprezentowano je w tabeli 2.

Tabela 2. Funkcje uniwersalne systemu ERP

\begin{tabular}{|c|c|}
\hline nkcji & 0 \\
\hline Projekty i & $\begin{array}{l}\text { Wsparcie śledzenia prac przewidzianych harmonogramem, śledzenie stopnia } \\
\text { wykonalności budżetu, śledzenie rentowności na każdym etapie projektu. }\end{array}$ \\
\hline Analizy & $\begin{array}{l}\text { entowanie raportów w wielu układach i przekrojach w wielu } \\
\text { iębiorstwa. }\end{array}$ \\
\hline $\begin{array}{l}\text { Automatyzacja pracy } \\
\text { obiegu dokumentów }\end{array}$ & $\begin{array}{l}\text { Umożliwia elektroniczne odzwierciedlenie procesów biznesowych w } \\
\text { przedsiębiorstwie poprzez np. elektroniczne repozytorium dokumentów, analizę } \\
\text { ścieżek obiegu dokumentów, modelowanie procesów biznesowych. }\end{array}$ \\
\hline ERP & $\begin{array}{l}\text { Umożliwienie korzystania z systemu ERP w modelu usługowym bez konieczności } \\
\text { zakupu serwerów i oprogramowania. }\end{array}$ \\
\hline
\end{tabular}

Źródło: jak w tabeli 1.

Zaprezentowane funkcje uniwersalne pozwalają twierdzić, że współczesne systemy ERP są $\mathrm{w}$ dużej mierze ukierunkowane na wysoki stopień digitalizacji procesów biznesowych przedsiębiorstwa, dużą łatwość analizy i prezentacji danych oraz wykorzystania ogromnego potencjału Internetu poprzez rozwój cloud computing.

Funkcje sprzedażowe systemu ERP zastały zaliczone przez autora do odrębnej grupy funkcji niż funkcje podstawowe z powodu ich wielości oraz wysokiego stopnia powiązania $\mathrm{z}$ nowymi technologiami internetowymi i mobilnymi. Zaprezentowano je $\mathrm{w}$ tabeli 3.

Tabela 3. Funkcje sprzedażowe systemu ERP

\begin{tabular}{|c|c|}
\hline Nazwa funkcji & Opis funkcji \\
\hline Rozwiązania B2B & $\begin{array}{l}\text { Umożliwia przedsiębiorstwom obsługę kontraktów z partnerami biznesowymi } \\
\text { przez elektroniczną wymianę danych EDI. }\end{array}$ \\
\hline $\begin{array}{l}\text { Sprzedaż za pomocą } \\
\text { aplikacji mobilnych }\end{array}$ & $\begin{array}{l}\text { Aplikacje przeznaczone dla kierowników działu sprzedaży i pracowników } \\
\text { wspierające pracę } \mathrm{z} \text { dowolnego miejsca } \mathrm{z} \text { wykorzystaniem urządzeń mobilnych. }\end{array}$ \\
\hline Sprzedaż internetowa & $\begin{array}{l}\text { Umożliwia stworzenie własnego sklepu internetowego zintegrowanego z } \\
\text { systemem ERP oraz znanymi portalami jak Allegro i Facebook. }\end{array}$ \\
\hline Sprzedaż detaliczna & Wsparcie sprzedaży sieciowej na linii sieć, sklep, stanowisko sprzedażowe. \\
\hline
\end{tabular}

Źródło: jak w tabeli 1.

Zaprezentowane funkcje sprzedażowe wskazują na rosnącą rolę obsługi transakcji elektronicznych zarówno B2B oraz B2C we współczesnych systemach ERP. Transakcje te są zintegrowane $\mathrm{z}$ procesami systemu ERP. Dzięki zastosowaniu elektronicznej wymiany danych w transakcjach B2B można przypuszczać, że systemy ERP umożliwiają w coraz większym stopniu realizację integracji zewnętrznej.

\section{System ERP jako innowacja}

Z perspektywy przedsiębiorstwa system ERP stanowi innowację o wysokim stopniu złożoności. Każda innowacja w przedsiębiorstwie bez względu na jej charakter (produktowy, procesowy lub organizacyjny) cechuje się typowymi podobnymi etapami jej wprowadzania w organizacji. Do etapów tych zalicza się:

${ }^{8}$ J. Tidd, J. Bassant, K. Pavitt: Managing Innovation, John Wiley and Sons, West Sussex 2005, s. 67-68. 
- wyszukiwanie - przeszukiwanie środowiska w celu identyfikacji zagrożeń i szans na zmianę,

- wybór - decyzja o tym, na które sygnały przedsiębiorstwo powinno odpowiedzieć,

- implementacja - wprowadzenie pomysłu w życie poprzez zdobywanie zasobów wiedzy, realizację projektu, wprowadzanie innowacji, modyfikację innowacji,

- uczenie się - zdobywanie wiedzy i doświadczenia z całego procesu innowacji.

Według teorii dyfuzji innowacji proces innowacji w przedsiębiorstwie można podzielić na dwa podprocesy noszące nazwy inicjacji oraz implementacji. Inicjacja obejmuje zbieranie informacji, konceptualizacje oraz planowanie adopcji innowacji. Z kolei implementacja obejmuje wszystkie działania związane $\mathrm{z}$ wprowadzeniem innowacji do użycia ${ }^{9}$. W tabeli 4 zamieszczono opis etapów innowacji w przedsiębiorstwie.

Tabela 4. Etapy procesu innowacji w organizacji według teorii dyfuzji innowacji

\begin{tabular}{|c|c|c|c|}
\hline Proces & Podproces & Etap & Opis etapu \\
\hline \multirow{5}{*}{ Innowacja } & \multirow[t]{2}{*}{ Inicjacja } & Ustalanie problemu & $\begin{array}{l}\text { Definiowanie problemu wywołującego } \\
\text { potrzebę innowacji. Ustalanie priorytetów } \\
\text { potrzeb. Poszukiwanie } \\
\text { rozwiązań problemu. }\end{array}$ \\
\hline & & Dopasowywanie & $\begin{array}{l}\text { Określenie na ile innowacja odpowiada } \\
\text { problemowi i na ile jest w stanie go } \\
\text { rozwiązać. }\end{array}$ \\
\hline & \multirow{3}{*}{ Implementacja } & Redefiniowanie & $\begin{array}{l}\text { Dostosowywanie innowacji do } \\
\text { przedsiębiorstwa w wyniku czego zmienia } \\
\text { się innowacja i przedsiębiorstwo. }\end{array}$ \\
\hline & & Wyjaśnianie & $\begin{array}{l}\text { Użycie innowacji na większą skalę w } \\
\text { przedsiębiorstwie w wyniku czego idea } \\
\text { innowacji staje się dla pracowników } \\
\text { przedsiębiorstwa bardziej zrozumiała }\end{array}$ \\
\hline & & Rutynizacja & $\begin{array}{l}\text { Wprowadzenie innowacji do powszechnego } \\
\text { użytku w przedsiębiorstwie. }\end{array}$ \\
\hline
\end{tabular}

Źródło: Opracowanie własne na podstawie E. Rogers, Diffusion of Innovation, Free Press, New York 2003, s. 417-429.

Proces innowacji $\mathrm{w}$ przedsiębiorstwie składa się $\mathrm{z}$ wielu etapów, z których każdy ma duże znaczenie dla powodzenia całego procesu. Faza implementacji musi mieć dobrą podstawę $\mathrm{w}$ odpowiednim zbadaniu i przeanalizowaniu problemu oraz dopasowania do niego odpowiedniego rozwiązania innowacyjnego. Jest to również bardzo złożony proces $\mathrm{w}$ wyniku, którego dostosowywana i zmieniana jest innowacja tak aby pasowała do specyfiki przedsiębiorstwa, ale także zmienia się samo przedsiębiorstwo i realizowane $\mathrm{w}$ nim procesy biznesowe na skutek wprowadzenia innowacji i konieczności dostosowania do niej praktyk przedsiębiorstwa. Proces ten jest również powolny $\mathrm{i} \mathrm{w}$ dużym stopniu zależy od odpowiedniego zaangażowania kierownictwa i pracowników w jego rozwój.

Proces dyfuzji systemów ERP w przedsiębiorstwach europejskich postępuje relatywnie szybko. Dane wskazują na istotny wzrost użycia systemów ERP w

${ }^{9}$ E. Rogers: Diffusion of Innovation, Free Press, New York 2003, s. 417-428. 
przedsiębiorstwach krajów Unii Europejskiej. W okresie pięciu lat od roku 2010 do 2015 odnotowano $15 \%$ wzrost z poziomu $21 \%$ do $36 \%$ przedsiębiorstw używających systemy $\mathrm{ERP}^{10}$. W Polsce udział przedsiębiorstw używających systemy ERP w 2015 r. był niższy od średniej unijnej i wynosił $21 \%{ }^{11}$.

\section{Wdrażanie złożonych systemów informacyjnych w przedsiębiorstwach}

Systemy ERP można zaliczyć do najbardziej rozbudowanych i złożonych systemów informacyjnych w przedsiębiorstwach. Dlatego też zakup systemu ERP stanowi jedną z głównych kategorii inwestycji w technologie informacyjne w przedsiębiorstwach. Wskazuje się na następujące istotne czynniki wyboru systemu informacyjnego ${ }^{12}$ :

- cechy oprogramowania - niezawodność i szybkość działania systemu, łatwość integracji z dotychczasowymi systemami w przedsiębiorstwie,

- technologia - kompatybilność z posiadanym sprzętem komputerowym oraz oprogramowaniem,

- wsparcie - zakres wsparcia, które oferuje dostawca systemu,

- koszty - cena systemu wraz z jego utrzymaniem,

- customizacja - dostępność customizowanych wersji systemu,

- siła dostawcy - reputacja, kondycja finansowa i doświadczenie dostawcy systemu.

W przedsiębiorstwie duże znaczenie ma wstępna faza wdrażania systemu informacyjnego jaką jest studium wykonalności ${ }^{13}$. Analizowana jest zarówno wykonalność organizacyjna jak i wykonalność ekonomiczna. Wykonalność organizacyjna obejmuje m.in. ocenę zgodności między korzyściami jakie zapewni nowy system informacyjny $i$ całą strategią biznesową przedsiębiorstwa. Istotne jest czy system informacyjny umożliwi przedsiębiorstwu osiagnięcie jego celów. Ważne jest również określenie nastawienie potencjalnych użytkowników do nowego systemu oraz $\mathrm{w}$ razie potrzeby określenie kroków zaradczych mogących zniwelować opór użytkowników przed zmianami. Z kolei w wykonalności ekonomicznej analizuje się koszty i korzyści z wprowadzenia systemu informacyjnego w przedsiębiorstwie. Analizie poddaje się zarówno namacalne jak i nienamacalne koszty i korzyści. Namacalne koszty i korzyści to takie którym można przyporządkować konkretne monetarne wartości. Z kolei nienamacalne to takie które trudno zmierzyć wartością pieniężną.

Cykl wdrożenia systemu ERP obejmuje etapy adopcji, implementację oraz etap postimplementacyjny ${ }^{14}$. Wprowadzanie systemu informacyjnego $\mathrm{w}$ przedsiębiorstwie jest obarczone dużym ryzykiem ze względu na dużą technologiczną złożoność

\footnotetext{
10 Eurostat: E-business integration, http://ec.europa.eu/eurostat/statistics-explained/index.php/Ebusiness_integration.

${ }^{11}$ Eurostat: Integration of internal processes

http://appsso.eurostat.ec.europa.eu/nui/show.do?wai=true\&dataset=isoc_bde15dip.

12 B. Sahay, A. Gupta: Development of software selection criteria for supply chain solutions, Industrial Management and Data Systems 103(2) 2003, s. 98-108.

${ }^{13}$ T. Gospodarek: Systemy ERP. Modelowanie, projektowanie, wdrażanie, Wyd. Helion 2016, s. 230.

${ }^{14}$ M. Markus, C. Tanis: The enterprise systems experience - from adoption to success (W:) Framing the domains of IT research, (ed. R. Zmud), Pinnaflex Educational Resources, Cincinati 2000, s. 204.
} 
przedsięwzięcia ${ }^{15}$. Ryzyko to znajduje się głównie na etapie adopcji i implementacji. Na przykład wybór nieodpowiedniego systemu lub dostawcy może spowodować niepowodzenie implementacji. $Z$ kolei użytkowanie systemu na etapie postimplementacyjnym może zmniejszyć ryzyko przedsiębiorstwa na skutek poprawy przez system przetwarzania informacji, większej dokładności informacji, integracji procesów przedsiębiorstwa, dzielenia informacji oraz koordynacji procesów ${ }^{16}$.

Badania nad systemami ERP wskazują na następujące ważne czynniki ich wdrażania w przedsiębiorstwie ${ }^{17}$ :

- na adopcję systemów ERP mają wpływ zarówno czynniki wewnętrzne tkwiące w przedsiębiorstwie, jak i zewnętrzne,

- dla adopcji systemów ERP istotne jest zaangażowanie kierownictwa oraz postrzegane przez nie potencjalne korzyści,

- duże przedsiębiorstwa mają większe możliwości i są bardziej skłonne do adopcji systemów ERP niż małe przedsiębiorstwa,

- dobre zarządzanie projektem zwiększa powodzenie adopcji ERP,

- na tempo dyfuzji systemów ERP w branży mają wpływ działania marketingowe dostawców systemów,

- na wybór rodzaju oprogramowania ERP ma wpływ dopasowanie do procesów biznesowych przedsiębiorstwa oraz presja ze strony partnerów w lańcuchu dostaw,

- na powodzenie projektu w fazie implementacji wpływ ma zarządzanie wiedza.

Badania dotyczące fazy implementacji wskazują na następujące czynniki sukcesu projektu ERP ${ }^{18}$ :

- rozumienie strategicznych celów - kierownictwo musi rozumieć dlaczego chce wprowadzić system ERP,

- zaangażowanie kierownictwa przedsiębiorstwa,

- doskonałe zarządzanie projektem - od projektu ERP wymaga się określenia celów, planowania zasobów, śledzenia postępu projektu,

- zarządzanie zmianą - ma duże znaczenie ponieważ pracownicy są zazwyczaj niechętni wprowadzaniu tego rodzaju zmian w przedsiębiorstwie,

- zespół implementujący system - zespół, a w szczególności konsultanci powinni mieć doświadczenie w implementacji określonego rodzaju systemu ERP,

- dokładność danych - istotne jest aby przenoszone do nowego systemu dane były poprawne, a formy zbierania, analizowania $\mathrm{i}$ raportowania danych $\mathrm{w}$ nowych systemach ERP były zgodne z wymaganymi standardami.

W fazie postimplementacyjnej duże znaczenie dla pełnego wykorzystania systemu ma chęć korzystania z niego przez użytkowników. Dlatego ważnymi cechami systemów ERP w fazie postimplementacyjnej jest łatwość użytkowania systemu.

\footnotetext{
${ }^{15}$ G. Seo: Challenges in Implementing Enterprise Resource Planning (ERP) system in Large Organizations: Similarities and Differences Between Corporate and University Environment, Working Paper CISL\# 2013-07, Composite Information Systems Laboratory (CISL), 2013, http://ic3.mit.edu/ResearchSamples/2013-07.pdf, s. $10-11$.

${ }^{16}$ A. Rai, R. Patnayakuni, N. Seth: Firm performance .... (Op. cit.), s. 240.

${ }^{17}$ M. Haddara, O. Zach: ERP Systems in SME: A Literature Review, Proceedings of 44 Hawaii International Conference on System Sciences, 2011, s. 3-5.

${ }^{18}$ E. Umble, R. Haft: Enterprise resource planning: implementation procedures and critical success factors, European Journal of Operational Research, 146(2) 2003, s.250-254.
} 
Badania przeprowadzone na $\mathrm{w}$ polskich przedsiębiorstwach dotyczące najbardziej pożądanych cech systemów ERP wykazały, że najwyżej ocenianą cechą jest wygoda korzystania z oprogramowania dla użytkownika (66\% respondentów) ${ }^{19}$.

\section{Podsumowanie i wnioski}

Od połowy lat dziewięćdziesiątych XX w. systemy te systematycznie ewoluowały od postaci oprogramowania planowania potrzeb materiałowych poprzez rozwiązania integrujące działy przedsiębiorstw, aż po współczesne rozwiązania wzbogacone o moduły obsługi sprzedaży B2B, B2C, sprzedaży za pomocą aplikacji mobilnych, przy wsparciu takich usług jak system ERP w chmurze oraz customizacja. Można tym samym stwierdzić, że w coraz większym stopniu przyczyniają się one do coraz większej automatyzacji procesów oraz są $\mathrm{w}$ coraz większym stopniu nakierowane na rozwój integracji zewnętrznej przedsiębiorstw.

Udana implementacja systemu ERP stanowi dla przedsiębiorstw duże wyzwanie. Systemy ERP są innowacjami o wysokim stopniu złożoności i każdy etap procesu innowacji ma duże znaczenie przy ich wprowadzaniu w przedsiębiorstwie. Na każdym z etapów procesu innowacji występuje wiele czynników mogących mieć wpływ na niepowodzenie projektu wdrażania ERP. Czynniki mające wpływ na rozwój systemu ERP mogą tkwić w przedsiębiorstwie jak i pochodzić z jego otoczenia.

W świetle zaprezentowanych rozważań można postawić tezę, że na największe ryzyko we wprowadzaniu systemów ERP narażone są przedsiębiorstwa w fazach adopcji i implementacji. W fazie adopcji szczególne znaczenie ma odpowiednie zdefiniowanie problemu oraz wybór oprogramowania najlepiej dopasowanego do potrzeb przedsiębiorstwa. Na etapie implementacji szczególnie istotne staje się umiejętne zarządzanie projektem, zaangażowanie kierownictwa oraz zarządzanie zmianą. Są to obszary i czynniki, z którymi szczególnie trudno jest sobie poradzić przedsiębiorstwom.

$\mathrm{Na}$ etapie postimplementacyjnym ryzyko niepowodzenia projektu jest mniejsze, lecz nadal ważne jest $\mathrm{w}$ tej fazie stałe usprawnianie i uczenie się systemu, zaangażowanie użytkowników systemu i łatwość jego obsługi.

\section{Bibliografia}

Bocij P., Chaffey D., Greasley A., Hickie S.: Business information systems, Pearson Education, Essex 2006.

Eurostat: E-business integration, http://ec.europa.eu/eurostat/statistics-explained/index.php/Ebusiness_integration.

Eurostat: Integration of internal processes,

http://appsso.eurostat.ec.europa.eu/nui/show.do?wai=true\&dataset=isoc_bde15dip.

Gospodarek T.: Systemy ERP. Modelowanie, projektowanie, wdrażanie, Wyd. Helion 2016.

Haddara M., Zach O.: ERP Systems in SME: A Literature Review, Proceedings of 44 Hawaii International Conference on System Sciences, 2011.

Kumar K., Van Hillsgersberg J.: ERP experiences and evolution, Communications of the ACM, 43(4) 2000.

\footnotetext{
${ }^{19}$ Monitor ERP System: Monitor ERP dokonał analizy potrzeb polskich firm produkcyjnych, 2016, http://www.monitorerp.com/pl/archives/date/2016/01/article.
} 
Lenart A.: Systemy ERP, (W:) Informatyka ekonomiczna (red. S. Wrycza), Wyd. PWE, Warszawa 2010.

Markus M., Tanis C.: The enterprise systems experience - from adoption to success (W:) Framing the domains of IT research, (ed. R. Zmud), Pinnaflex Educational Resources, Cincinati 2000.

Monitor ERP System: Monitor ERP dokonał analizy potrzeb polskich firm produkcyjnych, 2016, http://www.monitorerp.com/pl/archives/date/2016/01/article.

Partyka A.: Analiza porównawcza systemów klasy ERP, Współczesna Ekonomia Nr 2/2008(6).

Rai A., Patnayakuni R., Seth N.: Firm performance impacts of digital enabled supply chain integration capabilities, MIS Quarterly, 30(2) 2006.

Rogers E.: Diffusion of Innovation. Free Press, New York 2003.

Sadrzadehrafiei S., Chofreh A., Hosseini N., Sulaiman R.: The benefits of enterprise resource planning (ERP) system implementation in dry food packaging industry, Procedia Technology 11(2013).

Sahay B., Gupta A.: Development of software selection criteria for supply chain solutions, Industrial Management and Data Systems 103(2) 2003.

Seo G.: Challenges in Implementing Enterprise Resource Planning (ERP) System in Large Organizations: Similarities and Differences Between Corporate and University Environment, Working Paper CISL\# 2013-07, Composite Information Systems Laboratory (CISL), 2013, http://ic3.mit.edu/ResearchSamples/2013-07.pdf.

Tidd J., Bassant J., Pavitt K.: Managing Innovation, John Wiley and Sons, West Sussex 2005. Umble E., Haft R.: Enterprise resource planning: implementation procedures and critical success factors, European Journal of Operational Research, 146 (2) 2003.

\section{Summary}

The purpose of this article was to identify the factors that influence the process of implementing ERP systems. The aim was also to identify trends in ERP vendors' offer for enterprises in Poland. This article is based on a review of literature on the implementation of ERP systems and on secondary data available on the Internet. Analysis shows that modern ERP systems are increasingly contributing to the ever-increasing automation of processes and are increasingly focused on the development of external integration. The article also shows that at every stage of the innovation process there are many factors that may affect the failure of an ERP implementation project. Factors influencing the development of the ERP system can be embedded in the company as well as its surroundings.

Key words: ERP, enterprise resource planning, information systems, information technologies.

Informacja o autorze:

Dr Dariusz Strzębicki

Katedra Polityki Europejskiej i Marketingu

Wydział Nauk Ekonomicznych

Szkoła Główna Gospodarstwa Wiejskiego

e-mail: dariusz_strzebicki@sggw.pl 